\title{
The South China Sea Dispute and War/Peace Journalism: A Framing Analysis of a Malaysian Newspaper
}

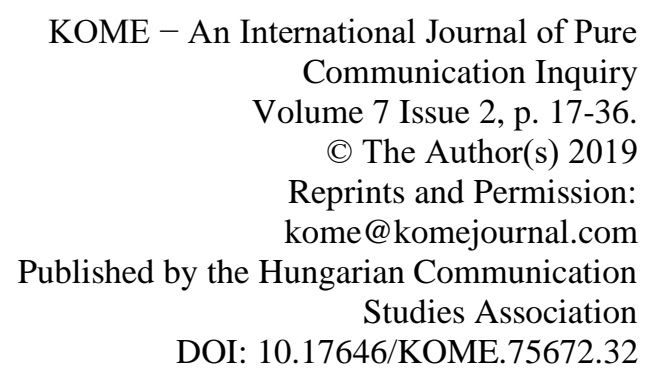

\begin{abstract}
News coverage of crises, conflicts, and wars is grounded in the notion of news value. Conflict reporting is often sensational and used as a device to boost circulation and ratings. Therefore, Norwegian Professor of Peace Studies Johan Galtung proposed peace journalism as a self-conscious working concept for journalists covering wars and conflicts. In recent years, tension has steadily increased over the South China Sea dispute. There are fears that the overlapping claims in the South China Sea will turn the region into an area of conflict, with potentially serious global consequences. This study aimed to examine the reporting of the South China Sea dispute by The Star, the English daily newspaper with the largest circulation in Malaysia. War/peace journalism and framing were employed as the theoretical framework, while content analysis was used as the research method to analyze the news coverage of the South China Sea dispute by The Star from 2014-2016. The findings showed that coverage in The Star was dominated by the war journalism frame but carried a neutral valence towards China. Implications of the findings to the understanding of war/peace journalism, conflict reporting, and news value studies were discussed.
\end{abstract}

Keywords: South China Sea dispute, war/peace journalism, framing, conflict reporting, crisis communication 